\title{
Sistem Zonasi dalam Perspektif Pendidikan
}

\author{
Asih Pangestuti 1 \\ 1Program Magister Universitas Jenderal Soedirman \\ E-mail: marsasih77@gmail.com
}

\begin{abstract}
This scientific study aims to determine the application of the zoning system from an educational perspective. The research was conducted using qualitative methods. The perspectives raised were the perspectives of students and teachers from favorite and not favorite schools. The results showed that the students 'and teachers' perspectives on the zoning system included: 1) the zoning system equalized access to education services; 2 ) the zoning system increases the spirit of teaching teachers; 3) the zoning system restricts students from choosing the desired school; 4) the zoning system causes weak students to miss lessons; 5) the zoning system causes bright students to have no challenges to improve achievement; 6) the zoning system increases the teaching load of teachers. The application of the zoning system must always be evaluated and improved in order to realize the quality of Education. The implementation of the zoning system must also be accompanied by equal distribution of public schools, school infrastructure, teacher resources, and educational assistance. Schools need to implement strategies in dealing with the zoning system through programs for developing student academic and non-academic potential, developing teacher competencies, and developing school culture.
\end{abstract}

Keywords: Perspective y of Education, school of strategy, Zoning.

\begin{abstract}
Abstrak
Studi ilmiah ini bertujuan untuk mengetahui penerapan sistem zonasi dalam perspektif pendidikan. Penelitian dilakukan dengan menggunakan metode kualitatif. Perspektif yang diangkat adalah perspektif siswa dan guru dari sekolah favorit dan tidak favorit. Hasil penelitian menunjukkan bahwa perspektif siswa dan guru tentang sistem zonasi antara lain meliputi: 1) sistem zonasi memeratakan akses layanan pendidikan; 2) sistem zonasi meningkatkan semangat mengajar guru; 3) sistem zonasi membatasi siswa untuk memilih sekolah yang diinginkan; 4) sistem zonasi menyebabkan siswa lemah tertinggal pelajaran; 5) sistem zonasi menyebabkan siswa pintar tidak memiliki tantangan untuk meningkatkan prestasi; 6) sistem zonasi menambah beban mengajar guru. Penerapan sistem zonasi harus selalu dievaluasi dan diperbaiki demi terwujudnya kualitas pendidikan. Penerapan sistem zonasi juga harus disertai pemerataan sekolah negeri, sarana prasarana sekolah, sumber daya guru, serta bantuan pendidikan. Sekolah perlu menerapkan strategi dalam menghadapi sistem zonasi melalui program pengembangan potensi akademis dan non akademis siswa, pengembangan kompetensi guru, dan pengembangan budaya sekolah.
\end{abstract}

Kata kunci: Perspektif Pendidikan, Strategi Sekolah, Zonasi.

\section{Pendahuluan}

Pendidikan pada dasarnya merupakan proses untuk membantu manusia dalam mengembangkan potensi dirinya sehingga mampu mengahdapi setiap perubahan yang terjadi. Dalam rangka pembangunan mmanusia Indonesia seutuhnya, pembangunan di bidang pendidikan merupakan suatu sarana penting dalam peningkatan kualitas sumber daya manusia. Oleh karena itu, pendidikan perl mendapatkan perhatian dari berbagai pihak seperti pemerintah, pengelola pendidikan, dan masyarakat. Dewasa ini sesuai dengan perkembangan masyarakat Indonesia, pendidikan banyak menghadapi berbagai 
hambatan dan tantangan. Salah satu tantangan yang cukup menarik adalah masalah ketimpangan pendidikan. Hal ini diperkuat hasil penelitian Vito, dkk.(2015) bahwa ketimpangan pendidikan masih terjadi, seperti ketimpangan pendidikan di perkotaan dan pedesaan. Ketimpangan pendidikan tersebut meliputi akses menuju sekolah, sarana prasarana sekolah seperti bangunan fisik, dan sumber daya guru (tenaga pengajar). Sarara prasarana pendidikan di perkotaan sangat lengkap dan kualitas guru sangat tinggi. Di sisi lain, sarana prasarana di pedesaan sangat terbatas dan kualitas guru masih rendah. Ketimpangan pendidikan pada akhirnya menyebabkan ketimpangan sumber daya manusia.

Pemerintah berupaya mengatasi ketimpangan pendidikan melalui kebijakan sistem zonasi. Tujuan utama sistem zonasi adalah pemerataan akses pendidikan serta pemerataan kualitas pendidikan. Upaya pemerataan akses layanan pendidikan akan memeratakan kualitas sumber daya manusia. Hal ini seperti disampaikan oleh Mashudi (2019) bahwa implementasi sistem zonasi mendorong pemerataan sumber daya manusia berkualitas. Sistem zonasi mengutamakan kedekatan jarak tempat tinggal calon siswa dengan sekolah. Berdasarkan Permendikbud No.44 Tahun 2019 pasal 11 menjelaskan bahwa penerimaan peserta didik baru dilakukan melalui empat jalur, meliputi jalur zonasi, afirmasi, perpindahan tugas orang tua, dan prestasi. Mengenai ketentuan zonasi telah tercantum pada pasal 11 Permendikbud Nomor 44 Tahun 2019, dimana sekolah wajib menerima calon siswa yang berdomisili pada radius zona terdekat dari sekolah paling sedikit 50\% dari daya tampung sekolah. Keterangan domisili ini dibuktikan dengan kartu keluarga yang diterbitkan paling lambat 1 (satu) tahun sejak tanggal pendaftaran penerimaan siswa baru. Kemudian jalur afirmasi $15 \%$, jalur perpindahan tugas orang tua/wali $5 \%$ dari daya tampung sekolah.

Implementasi sistem zonasi sudah berjalan secara serentak di seluruh Indonesia sejak tahun 2018. Seiring dengan implementasi sistem zonasi telah menimbulkan pro dan kontra di masyarakat. Berikut diuraikan beberapa hasil penelitian sebelumnya yang menjadi bahan rujukan penelitian ini. Penelitian tentang Persepsi masyarakat terhadap implementasi kebijakan zonasi sekolah dalam penerimaan peserta didik baru (PPDB) tingkat SMA tahun ajaran 2017/2018 di Kota Samarinda (Bintoro, 2018) menjelaskan, pertama, adanya kekawatiran orang tua akan tertutupnya kemungkinan untuk bersekolah di luar zonasi. Kedua, kurangnya sosialisasi kebijakan zonasi menimbulkan gejolak di masyarakat Ketiga, adanya kekawatiran perihal standar pendidikan yang tidak merata. Meski sistem zonasi bertujuan untuk pemerataan pendidikan yang berkualitas, namun terdapat kekawatiran tentang tepat tidaknya kebijakan ini diterapkan di daerah, khususnya Samarinda. Seharusnya sebelum dibelakukan sistem zonasi, distandarkan dulu semua sekolah, terutama standar mutu guru dan sarana prasarana. Selanjutya penelitian yang berjudul tentang strategi sekolah dalam menghadapi sistem zonasi studi di SMP N 3 Mrebet Purbalingga (Asep Henry Habbullah, 2018). Beberapa strategi yang dilakukan SMP N 3 Mrebet Purbalingga, adalah sebagai berikut: pertama, Branding Sekolah (Pencitraan Sekolah), adalah suatu cara seseorang membedakan satu sekolah dengan sekolah lainnya. Kedua, Strategi jemput bola yang dilakukan SMP N 3 Mrebet Purbalingga ada dua, yaitu 1) sekolah (guru) berkunjung ke SD-SD sekitar, dan 2) sekolah mengundang para guru dan calon siswa 
(anak kelas VI) untuk berkunjung ke sekolah. Ketiga, meningkatkan perfoma atau pelayanan yang bagus, baik terhadap siswa, orang tua, komite, dan entitas masyarakat lainnya. Keempat, pemberian beasiswa.

Ada perbedaan penelitian ini dengan penelitian sebelumnya. Pada penelitian sebelumnya meneliti tentang persepsi masyarakat (orang tua) dan meneliti tentang strategi sekolah dalam menghadapi sistem zonasi. Berdasarkan latar belakang tersebut, peneliti ingin mengkaji lebih lanjut mengenai sistem zonasi dalam persepektif pendidikan yang meliputi unsur siswa dan guru.

\section{Metode Penelitian}

Penelitian ini menggunakan metode penelitian kualitatif. Menurut Moleong (2017) penelitian kualitatif bermaksud untuk memahami fenomena yang dialami subjek penelitian, seperti perilaku, persepsi, motivasi, tindakan, dan lain-lain secara holistik dan dengan cara deskripsi dalam bentuk kata-kata dan bahasa, pada suatu konteks khusus yang alamiah dan dengan memanfaatkan berbagai metode alamiah. penelitian kualitatif adalah Metode ini dipilih untuk mendapatkan gambaran secara mendalam tentang sistem zonasi dalam perspektif pendidikan. Melalui penelitian kualitatif, diharapkan permasalahan sistem zonasi yang ditemui di lapangan dapat dijelaskan dan diterangkan secara rinci, sehingga akan memberikan kemudahan bagi orang lain yang ingin mengetahui tentang pembahasan dalam penelitian ini. Lokasi penelitian di lakukan di SMA-SMA yang ada di Kabupaten Kebumen. Subjek penelitian meliputi siswa dan guru. Metode pengambilan sampel dilakukan secara purposive sampling, yaitu peneliti memilih informan yang memahami dan memiliki pengalaman tentang sistem zonasi sehingga diperoleh informasi yang sesuai dengan keinginan peneliti. Metode pengumpulan data dilakukan dengan wawancara, observasi, dan dokumentasi. Validasi data dilakukan dengan validitas sumber dan metode. Sedangkan analisis data dilakukan berdasarkan model analysis interactive dari Miles Huberman yang terdiri atas pengumpulan data, reduksi data, penyajian data, dan penarikan kesimpulan.

\section{Hasil dan Pembahasan}

Kegiatan penelitian dilaksanakan di sekolah menengah atas yang ada di wilayah Kabupaten Kebumen. Ada dua sekolah yang dipilih peneliti, pertama SMA Negeri 1 Kebumen yang berada di pusat kota tepatnya di jalan Mayjen Sutoyo Nomor 7 Kebumen. Sekolah ini dikenal sebagai sekolah favorit yang diminati oleh masyarakat Kebumen dan sekitarnya. Sekolah ini memiliki fasilitas lengkap, tenaga pengajar yang berkualitas, memiliki tingkat kelulusan yang tinggi, dan sebagaian besar siswa meneruskan ke perguruan tinggi. Kedua, SMA Negeri 1 Pejagoan yang berada di pinggiran kota tepatnya di Jalan Soka KM 4 Kebulusan Pejagoan. Sekolah ini dikenal sebagai sekolah yang tidak favorit dan kurang diminati oleh masyarakat. Sekolah ini memiliki sarana prasarana yang cukup lengkap dan tenaga pengajar yang kompeten di bidangnya. Berdasarkan data dari guru Bimbingan Konseling (BK) menjelaskan bahwa sebagian siswa SMA Negeri 1 Pejagoan meneruskan ke perguruan tinggi, dan sebagian lainnya tidak meneruskan ke perguruan tinggi atau memilih bekerja setelah lulus. Keadaan tersebut tidak terlepas dari faktor sosial ekonomi orang tua siswa yang pada umumnya berasal dari keluarga menengah ke bawah dan bekerja sebagai petani maupun berdagang.

Pada implementasi sistem zonasi, pendaftaran siswa baru dilaksanakan melalui 
4 (empat jalur), yaitu jalur zonasi, afirmasi, perpindahan orang tua, dan prestasi. Jumlah siswa baru berdasarkan jalur pendaftaran siswa baru pada tahun 2020 diketahui bahwa sebagian besar siswa SMA Negeri 1 Kebumen masuk melalui jalur zonasi sebanyak 53\% (lima puluh tiga persen), jalur afirmasi sebanyak 15\% (lima belas persen), jalur perpindahan orang tua sebanyak $2 \%$ (dua persen), dan melalui jalur prestasi sebanyak $30 \%$ (tiga puluh persen). Sedangkan di SMA Negeri 1 Pejagoan, jumlah siswa yang masuk melalui jalur zonasi sebanyak 64\% (enam puluh empat persen), jalur afirmasi sebanyak $6 \%$ (enam persen), jalur perpindahan orang tua (-), dan jalur prestasi sebanyak 30\% (tiga puluh persen). Berdasarkan data tersebut dapat dijelaskan bahwa sebagain besar siswa masuk sekolah berdasarkan jalur zonasi. Hal ini menunjukkan bahwa implemetasi sistem zonasi berjalan sesuai dengan aturan pemerintah yaitu jalur zonasi minimal $50 \%$ dari keseluruhan daya tampung siswa.

Seiring dengan implementasi sistem zonasi di lapangan telah menimbulkan pro dan kontra di masyarakat, termasuk siswa dan guru. Mereka merupakan pihak yang terlibat langsung dalam pelaksanaan sistem zonasi mulai dari tahap sosialisasi, tahap pelaksanaan pendaftaran siswa baru, tahap pengumuman hasil penerimaan siswa baru, hingga proses pembelajaran. Pengetahuan yang dimiliki mereka menjadi dasar untuk membangun persepsi tentang sistem zonasi. Hal ini diperkuat oleh pendapat Toha (1988), persepsi adalah proses kognitif yang terjadi pada setiap orang dalam memahami informasi terhadap lingkungannya, yang diperolehnya melalui penglihatan, pendengaran, penghayatan, perasaan, maupun pengalaman. Ada pengalaman positif dan negatif yang mereka peroleh sehingga menjadi dasar bagi mereka untuk memaknai sistem zonasi.
Para siswa setuju dengan sistem zonasi karena menimbulkan dampak positif. Dampak positif sistem zonasi adalah dapat meningkatkan akses pemerataan pendidikan. Saat ini semua siswa baik yang berasal dari kota maupun dari desa, dari kalangan atas maupun bawah, yang berprestasi maupun tidak berprestasi memiliki kesempatan yang sama untuk mendapatkan pendidikan yang berkualitas. Semua siswa diharapkan untuk masuk ke sekolah yang terdekat dengan tempat tinggalnya. Kedekatan jarak antara satu siswa dengan siswa lainnya juga memudahkan komunikasi dan kerja sama antarsiswa, termasuk dalam pengerjaan tugas-tugas. Kedekatan jarak juga mendukung mereka untuk lebih saling mengenal satu sama lain sehingga tidak mengalami kesulitan dalam bergaul. Mereka juga tidak harus jauh jauh untuk mengerjakan tugasa bersama namun cukup belajar kelompok atau mengerjakan tugas kelompok dengan teman-teman yang rumahnya saling berdekatan. Hal ini dapat meningkatkan semangat belajar siswa. Namun, ada pula siswa yang tidak setuju tentang sistem zonasi karena menimbulkan dampak negatif. Sistem zonasi dianggap membatasi siswa berprestasi untuk memilih sekolah. Sistem zonasi juga dapat membuat siswa lemah tertinggal materi pelajaran. Dampak berikutnya adalah sistem zonasi menyebabkan siswa berprestasi tidak tertantang untuk berprestasi.

Para guru setuju dengan sistem zonasi karena menimbulkan dampak positif. Dampak positif sistem zonasi adalah meningkatkan semangat mengajar. Sejak implementasi sistem zonasi telah mengubah komposisi siswa yang semula homogen menjadi heterogen. Saat ini siswa berkumpul dalam satu kelas, ada siswa yang pintar dan ada pula siswa yang lemah. Tentunya mereka membutuhkan pelayanan yang berbeda-beda 
agar memperoleh hasil belajar yang baik. Menghadapi situasi seperti itu, guru akan semakin tertantang untuk menguasai berbagai strategi pembelajaran. Strategi belajar ini meliputi metode mengajar, media mengajar, sumber belajar, dan sebagainya. Namun ada pula guru yang berpandangan tidak setuju karena sistem zonasi dianggap menambah beban mengajar. Berhadapan dengan siswa-siswa yang memiliki kemampuan belajar berbeda-beda membuat guru harus mengajar ekstra keras, terutama ketika berhadapan dengan siswa-siswa yang berkemampuan rendah/lemah.

Implementasi sistem zonasi harus selalu dievaluasi dan diperbaiki demi terwujudnya kualitas pendidikan. Evaluasi sistem zonasi yang sudah dilakukan oleh pemerintah antara lain meliputi penambahan jalur pendaftaran, perubahan kuota di setiap jalur pendaftaran, penggunaan Surat Keterangan Domisili (SKD) sebagai pengganti Kartu Keluarga (KK), dan sebagainya. Implementasi sistem zonasi juga harus disertai pemerataan sekolah negeri, sarana prasarana sekolah, sumber daya guru, serta bantuan pendidikan. Hal ini agar tujuan pemerintah untuk mewujudkan pemerataan kualitas pendidikan dapat tercapat. Sekolah merespon dampak negatif implementasi sistem zonasi dengan menerapkan berbagai strategi. Strategi sekolah dibangun dengan mengoptimalkan kekuatan dan peluang yang ada untuk mengahdapi berbagai hambatan dan ancaman. Beberapa strategi sekolah untuk menghadapi implementasi sistem zonasi antara lain program penguatan pengembangan potensi akademis dan nonakademis siswa, pengembangan kompetensi guru, dan pengembangan budaya sekolah.

SMA Negeri 1 Kebumen, melakukan optimalisasi pengembangan potensi akademis dan non akademis dengan memberikan kelas tambahan bagi siswa yang memiliki kemampuan akademis rendah. Sekolah akan memetakan siswa berdasarkan kemampuan akademis. Bagi siswa yang berkemampuan rendah akan dilakukan bimbingan belajar secara khusus sehingga dapat menyesuaikan diri dengan proses pembelajaran pada umumnya. Sekolah juga mendukung pengembangan bakat dan minat siswa melalui kegiatan ekstrakurikuler seperti pramuka, olah raga, seni, agama, maupun sain club. Di SMA Negeri 1 Pejagoan, optimalisasi pengembangan potensi akademis dan non akademis dilakukan dengan pemetaan siswa berdasarkan kemampuan akademis untuk memfasilitasi siswa unggulan, dan pengembangan bakat minat siswa melalui pengembangan ekstrakurikuler.

Pengembangan kompetensi guru yang dilakukan di SMA Negeri 1 Kebumen maupun di SMA Negeri 1 Pejagoan dilakukan dengan mengadakan berbagai kegiatan pengembangan keprofesian berkelanjutan seperti seminar, pelatihan, workshop tentang metode mengajar, media mengajar, dan sebagainya. Guru juga mengikuti kegiatan training motivation untuk menambah semangat mengajar meraka dan mengajarkan tentang cara-cara menghadapi siswa-siswa bermasalah. Pengembangan budaya sekolah yang dilakukan SMA Negeri 1 Kebumen adalah program Gerakan Literasi Sekolah (GLS). Program ini bertujuan untuk meningkatkan kemampuan membaca dan menulis siswa. Program Gerakan Literasi Sekolah meliputi kegiatan membaca pada jam ke-0, mengadakan perpustakaan kelas, mendirikan pojok baca, lomba literasi, dan sebagainya. Pengembangan budaya sekolah yang dilakukan SMA Negeri 1 Pejagoan adalah kegiatan sholat berjamaah dan budaya Senyum-Salam-Sapa. 


\section{Simpulan}

Sistem zonasi menimbulkan perspektif yang berbeda beda pada siswa dan guru. Perbedaan perspektif ini didasarkan pengetahuan dan pengalaman yang dialami oleh siswa selama proses sosialisasi, pelaksanaan pendaftaran, hingga proses pembelajaran. Sedangkan pengetahuan dan pengalaman guru diperoleh sejak sosialisasi sistem zonasi hingga proses pembelajaran. Siswa setuju dengan sistem zonasi menimbulkan dampak positif, seperti dapat meningkatkan akses pemerataan pendidikan, memberikan kemudahan bagi siswa untuk masuk ke sekolah yang terdekat dengan tempat tinggalnya, dan meningkatkan semangat belajar siswa. Namun, ada pula siswa yang tidak setuju tentang sistem zonasi karena menimbulkan dampak negatif

\section{Daftar Pustaka}

Aprilia DMS, Mellynia. Pengaruh Penerimaan Peserta Didik Baru Melalui Sistem Zonasi Dalam Dunia Pendidikan. INA-Rxiv_Papers. https://osf.io/preprints/inarxiv/h xepv/

Bustomi, M.J. (2012). Ketimpangan Pendidikan Antar Kabupaten/Kota Dan Implikasinya Di Provinsi Jawa Tengah. Economics Development Analysis Journal.Vol1.(2). p.1-10. https://journal.unnes.ac.id/sju/in dex.php/edaj/article/view/477

Hanifah, LN.\& Wahyudi, TN. (2019). Persepsi Orang Tua Murid Terhadap Kebijakan Sistem Zonasi Sekolah Dalam Penerimaan Peserta Didik Baru Di Tingkat SMA N Di Wilayah Wonogiri. Skripsi. UMS. Surakarta. http://v2.eprints.ums.ac.id/archiv e/etd/78523 anggapan bahwa sistem zonasi membatasi siswa berprestasi untuk memilih sekolah dan membuat siswa lemah tertinggal materi pelajaran.

Guru setuju dengan sistem zonasi karena menimbulkan dampak positif seperti dapat meningkatkan kualitas sekolah, menguntungkan sekolah pinggiran karena banyak siswa berprestasi yang masuk, dan meningkatkan semangat mengajar. Namun ada pula guru yang tidak setuju karena sistem zonasi dianggap menambah beban mengajar. Sekolah merespon dampak negatif implementasi sistem zonasi melalui pengembangan potensi akademis dan nonakademis, pengembangan bakat dan minat siswa, serta pengembangan budaya sekolah.

Jalaluddin Rakhmat. (2011). Psikologi Komunikasi. Bandung: PT. Remaja Rosdakarya.

Lutfi, FS. (2005). Kualitas Pendidikan di Indonesia. Jurnal Indonesia. 1. P.14.

https://s3.amazonaws.com/acade mia.edu.documents/58019092

Martono, N. (2017). Sekolah Publik VS Sekolah Privat. Dalam Wacana Kekuasaan, Demokrasi, dan Liberalisasi. Jakarta: Yayasan Pustaka Obor Indonesia.

Marx, Karl. (2004). Kapital 1: Proses Produksi Kapitalis. Yogyakart: Hasta Mitra.

Mashudi, Ahmad.(2018). Kebijakan PPDB Sistem Zonasi SMA/SMK Dalam Mendorong Pemerataan Kualitas SDM Di Jawa Timur. Jurnal Manajemen Pendidikan Islam. Hal.186-206. http://ejournal.ikhac.ac.id/index.php/nidhom ulhaq/article/view/327 
Moleong, L. J. (2017). Metode Penelitian Kualitatif. Bandung: Remaja Rosdakarya Ofset.

Sardiman, A.M. (2014). Interaksi dan Motivasi Belajar Mengajar. Jakarta: Rajawali.

Safarah, A.A. dan Wibowo, UB. (2018). Program Zonasi Di Sekolah Dasar Sebagai Upaya Pemerataan Kualitas Pendidikan. Jurnal Lentera Pendidikan. Vol.21.(2).p. 206-213. http://journal.uinalauddin.ac.id/index.php/lentera pen didikan/article/view/206-213
Saputra, A. (2008).Menuju Sistem Pendidikan Global. Jurnal Fakultas Hukum UII. Hal.1-15.

https://journal.uii.ac.id/Unisia/art icle/view/172

Sutaryo. (2004). Dasar-Dasar Sosioalisasi. Jakarta: Rajawali Press.

Thoha Miftah. (2009). Perilaku Organisasi: Konsep Dasar dan Aplikasinya. Jakarta: Raja Grafindo Persada

Vito, B., Krisnani.H., \& Resnawaty. R.,(2015) Kesenjangan Pendidikan Desa Dan Kota . Jurnal Unpad/Prosiding Ks: Riset \& Pkm Volume: 2 (2) p.147300. 